\title{
The Orientation of Equipment Technology in Improving Production Performance in Batik SMEs
}

\author{
Chauliah Fatma Putri ${ }^{1, *}$ Muhammad Agus Sahbana ${ }^{2}$
}

\author{
${ }^{1}$ Industrial Engineering, University of Widyagama Malang, 65125, Indonesia \\ ${ }^{2}$ Mechanical Engineering, University of Widyagama Malang, 65125, Indonesia \\ *Corresponding author. Email: chauliah@widyagama.ac.id
}

\begin{abstract}
Written batik is a work of art that is recognized worldwide as an original Indonesian cultural heritage. The production process of written batik is carried out traditionally and from generation to generation in Solo and Yogyakarta as the oldest batik development areas in Indonesia. Making written batik is a challenge for batik makers. The manufacturing process is long, while productivity tends to below. The extent to which the use of batik production equipment technology is used to produce written batik products is a concern in this study. To analyse each of the effects of the technology orientation of the drawing table, canting, canting cap, padder, and kenceng on the written batik production process and the effect of equipment technology orientation simultaneously on the production performance of written batik Small Medium Entrepreneur (SMEs) in Central Java. The method used is the multiple linear regression statistical test with SPSS. Applied to test the effect of using each tool on written batik SMEs respondents in Solo and Yogyakarta. The results showed that the production performance of batik SMEs in Central Java was influenced by the technology orientation of the tools used simultaneously. The technology orientation of each tool, namely the drawing table, canting cap, and padder, affects the performance of written batik production. Meanwhile, the orientation of the canting and kenceng technology has no significant effect on the performance of written batik production.
\end{abstract}

Keywords: Written Batik, Machine, Production Performance, SMEs, Tools.

\section{INTRODUCTION}

Since October 2, 2009, batik has been recognized by the United Educational, Scientific, and Cultural Organization (UNESCO) as a non-material cultural heritage, namely the original Cultural Heritage from Indonesia [1]. The production system can run well if the input is in the form of a production factor according to the needs of the production process so that useful production output is produced as expected. The condition of Batik SMEs in Central Java, especially Surakarta and Yogyakarta, are 2 of the 3 oldest batik development centers in Indonesia. Written batik products are art products based on local wisdom and are unique because batik in each region has its characteristics. The production process still maintains the true definition of batik. The production process of batik making, which is traditionally passed down from generation to generation, should not be a barrier to batik production that develops innovatively and technology, without leaving the true characteristics of batik.
According to [2], appropriate technology in practice applies modern management concepts to optimize production results or income. Application towards optimizing the production results or income of the batik industry requires the use of technology that is following the target, namely innovative technology in the form of tools and methods/techniques/methods along with assistance during use, Intellectual Property Rights made so that the technology designed, made and applied has patent rights and is protected, training in the application of appropriate new technology. According to [2], an indicator of appropriate technology is the conversion of natural resources, absorbed labour, triggered home industries, and increasing community income. Similar research usually only focuses on a tool or effort to increase productivity but does not look for components that contribute to productivity itself and carry out on a manufacturing scale. In this study, researchers looked for components that might affect the productivity of SMEs and then looked for the components that had the most influence on productivity, so that they could become the attention of SMEs. The components that support 
productivity in SMEs are collected and then processed by data processing so that the data obtained will show the components that have the most influence on productivity and the relationship between these components.

The factors for increasing productivity in this study are focused on the machines/equipment used in the batik production process. The purpose of this study was to determine the effect of the technology orientation of written batik production equipment on the performance of written batik production in Batik SMEs in Central Java. This process is a benchmarking process in the scope of the SMEs Batik production process in the batik producing cities regarding the means of batik production, namely Surakarta and Yogyakarta.

\section{METHOD}

The sampling technique used is probability sampling, which is a technique that provides equal opportunities or opportunities for each element or member of the population to be selected as samples. The sample in this study used a random sampling technique. The analysis technique used is multiple linear regression, namely regression analysis used to determine how the dependent variable can be predicted through the independent variable partially or simultaneously.

The variables taken in this study have six variables in the form of production equipment that has different technological orientations, namely, drawing table, canting, canting cap, padder, kenceng, and productivity. With the number of respondents totaling 65 respondents.

\section{RESULT AND DISCUSSION}

Figure 1 shows model of influence of technology orientation on production performance written batik SMEs. Meanwhile, drawing table, canting, canting cap, padder and kenceng are presented in Figure 2 to Figure 6.

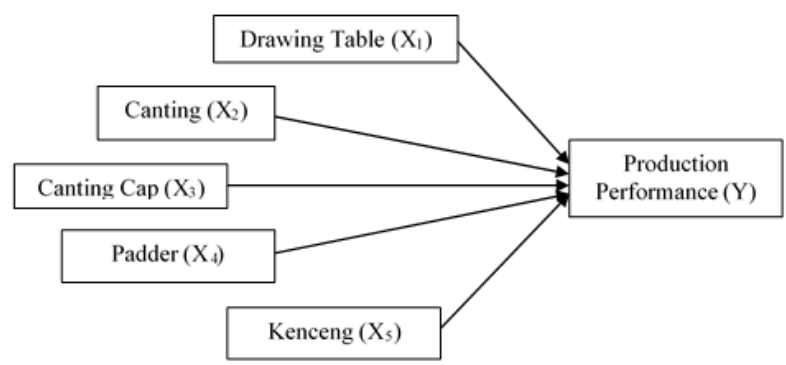

Figure 1 Model of influence of technology orientation on production performance written batik SMEs

The explanation for Figure 1 is as follows:

a. The drawing table is a table used to draw batik patterns on cloth. The drawing table can be an ordinary flat board table or an ergonomic table which is generally made of glass with wooden or metal supports, and frames equipped with lamps, and the table surface is mounted with a certain slope to comfort the body and eyes in drawing work.

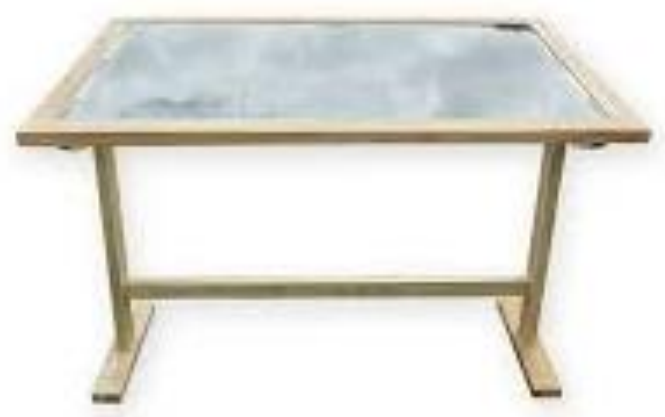

Figure 2 Drawing table

b. Canting is a tool used to carve liquid wax according to the drawing pattern of the liquid candle holder made of metal and a hole like a pen at the end of the candle holder, and with a wooden stick as a handle. This canting is called manual canting. To fill the melted wax in the container bag, this canting is dipped in melted wax in the pan, which is generally heated using a stove. While the electric canting is a canting which is used to heat the candle at the end of the container using electrical energy.
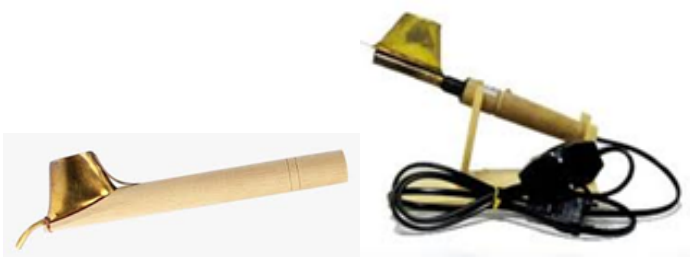

Figure 3 Canting

c. Canting cap is a canting that already has a certain motif or pattern and is made of a metal plate, either copper or other. This canting stamp usually has a variety of standard motifs or various other motifs that are already available in the market, or are the creativity of the owner, so the motives or patterns are very diverse.

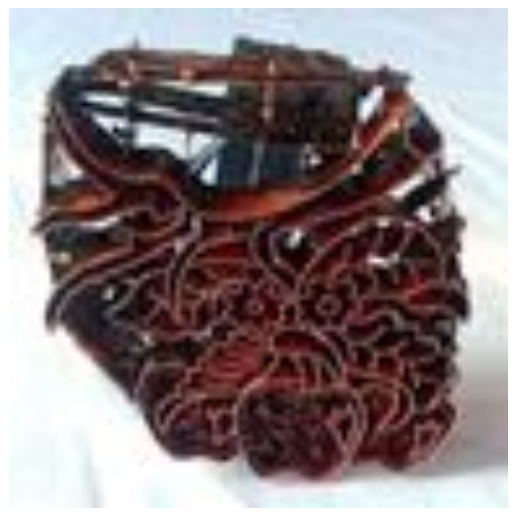

Figure 4 Canting cap 
d. Padder is a tool for the process of color strengthening (color fixation) on batik cloth. The padder consists of a tub and a roller. In this coloring process, chemical additives other than dyes are used. This tool makes it easier for the dye to absorb more quickly and evenly into the fabric fibers so that the color results of batik are better and the process is faster. In general, another alternative with economic considerations, this color strengthening process is carried out by immersing it in the bath only, without the roller which functions to suppress and strengthen the absorption of the dye liquid in the fabric fibers.

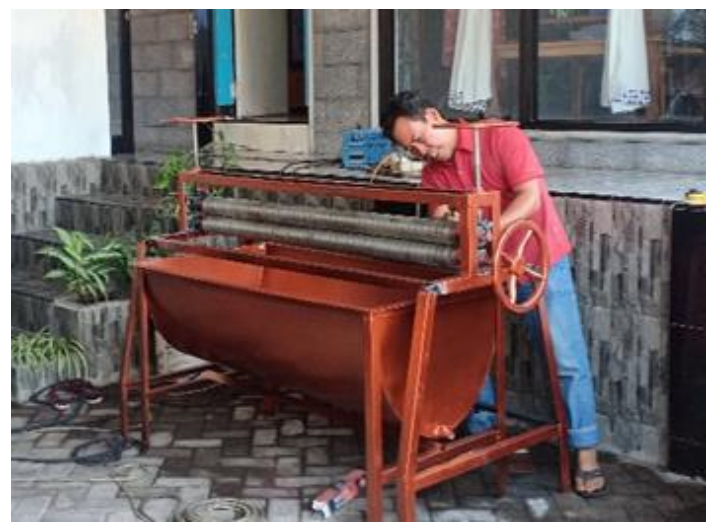

Figure 5 Padder

e. Kenceng is a tool to shed wax on batik cloth using hot water. Kenceng is shaped like a barrel which is generally large and made of copper metal. Heating is usually equipped with a stove. This copper plate is a good conductor, can provide fast heat, and can withstand heat for a long time, making it more energy-efficient. Also, it can give the impact of batik coloring that is better in color than with other heating materials. An alternative tool from kenceng with economic considerations, in general, a large regular cormorant is used.

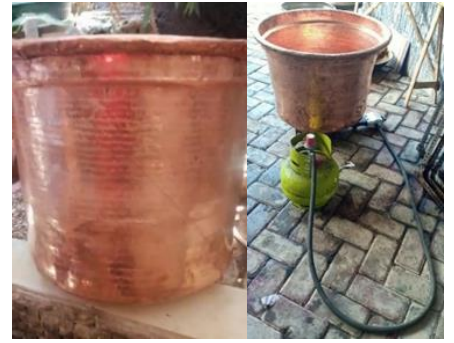

Figure 6 Kenceng

f. Production performance is the result of the work of the batik-making process. The measurement used is the production level in units of batik cloth products.

\subsection{Presenting the Results}

The results of the analysis using statistical tests are presented in Table 1 to Table 4.

Table 1. Descriptive Statistics

\begin{tabular}{lccc} 
& Mean & Std. Deviation & N \\
Production & 134.38 & 274.086 & 65 \\
Performance & & & \\
\hline Drawing Table & .12 & .331 & 65 \\
\hline Canting & .48 & .503 & 65 \\
\hline Canting Cap & .29 & .458 & 65 \\
\hline Kenceng & .92 & .269 & 65 \\
\hline Padder & .11 & .312 & 65 \\
\hline
\end{tabular}

From the descriptive data table above, it can be interpreted that most batik SMEs in Yogyakarta and Surakarta use ordinary drawing tables instead of ergonomic drawing tables. For canting, the average use of regular canting rather than electric canting. Meanwhile, the canting cap, about a third of SMEs has used the canting cap. For kenceng, almost all SMEs have used standard copper kenceng instead of ordinary aluminum corms (dandang). As for the padder, most use a padder that uses a roller rather than a regular tub.

Table 2. Model Summary ${ }^{b}$

\begin{tabular}{clllllll}
\hline Model & R & R Square & Adjusted R Square & $\begin{array}{l}\text { Std. Error of the } \\
\text { Estimate }\end{array}$ & $\begin{array}{l}\text { R Square } \\
\text { Change }\end{array}$ & F Change & df1 \\
\hline 1 & $.922^{\mathrm{a}}$ & .850 & .837 & 110.585 & .850 & 66.831 & 5 \\
\hline
\end{tabular}

Table 3. ANOVA

\begin{tabular}{clccccc}
\hline Model & & Sum of Squares & df & Mean Square & F & Sig. \\
\hline 1 & Regression & 4086366.486 & 5 & 817273.297 & 66.831 & $.000^{\mathrm{b}}$ \\
& Residual & 721512.899 & 59 & 12229.032 & & \\
& Total & 4807879.385 & 64 & & & \\
\hline
\end{tabular}

a. Dependent Variable: Production Performance

b. Predictors: (Constant), Padder, Kenceng, Canting, Drawing Table, Canting Cap 
Table 4. Coefficients

\begin{tabular}{lllccccc}
\hline Model & & Unstandardized B & $\begin{array}{c}\text { Coefficients } \\
\text { Std. Error }\end{array}$ & $\begin{array}{c}\text { Standardized } \\
\text { Coefficients } \\
\text { Beta }\end{array}$ & t & Sig. \\
\hline 1 & (Constant) & -65.93 & 66.289 & & -.983 & .329 \\
& Drawing table & 180.191 & 47.046 & .218 & 3.830 & .000 \\
& Canting & -5.394 & 30.094 & -.010 & -.179 & .858 \\
& Canting Cap & 115.062 & 38.147 & .192 & 3.016 & .004 \\
& Kenceng & 85.395 & 58.249 & .084 & 1.466 & .148 \\
& Padder & 626.910 & 54.813 & .715 & 11.437 & .000 \\
\hline
\end{tabular}

The descriptive statistics table presents the Figure Table variable (X1); Canting (X2); Canting Cap (X3); Padder (X4); Kenceng (X5) and Production Variables (Y).

The descriptive results of the production performance variable (Y) explain the mean (mean) of 134.38 with a standard deviation of 274.086 indicating that the results are still not good enough. This can be explained because the standard deviation reflects the magnitude of the deviation. Likewise, the descriptive table of figures (X1) shows a mean of 0.12 , with a standard deviation of 0.331 ; the descriptive results of the canting variable (X2) with a mean of 0.48 and a standard deviation of 0.503 ; the descriptive results of the canting cap variable (X3) with a mean of 0.29 and a standard deviation of 0.458 ; the descriptive results of the variable Kenceng (X5) with a mean of 0.11 and a standard deviation of 0.312 ; that is, the results are still not good enough. Except for the descriptive results for the Padder variable (X4), it is explained that the mean is 0.92 and the standard deviation is 0.269 indicating quite good results. The results of the Model Summary table show that the R-value is 0.922 and the coefficient of determination (R-square) is 0.850 (is the square of the value $0.9222=0.850$. This shows that production performance $(\mathrm{Y})$ is influenced by $85 \%$ by the variable Figure Table (X1). ); Canting (X2); Canting Cap (X3); Padder (X4); Kenceng (X5), while the rest (100\% $-85 \%=15 \%$ ) is explained by other reasons. $\mathrm{R}$ square ranges from 0 to 1 , with a note that the smaller the $R$ square number the weaker the relationship between the two or more variables.

The results of the Anova test, in this section, the results obtained are the value of $F=66,831$ with a sig probability level. 0.000 . because the probability $(0.000)$ is much smaller than 0.05 , a multiple regression model is used to predict the yield.

The results of the Coefficients test, on the table of the figure, found the constant value (a) $=-65.193$; table of figures $=180,191$ and $\mathrm{t}$-count $=1,900$ with sig. $=0.000$. Etc. The constant of $-65,193$ states that if there is no increase in drawing table usage, the production performance is $-65,193$. The regression coefficient of 180,191 states that each addition (due to the + sign) using the 180,191 drawing table will increase the production yield by 180,191 . Conversely, if you don't use the drawing table, the production result is also predicted to decline by 180,191 .

Based on the $\mathrm{t}$ value in table 4 above which is compared with the table of 2,000 for the figure table, then $\mathrm{HO}$ is rejected and $\mathrm{Ha}$ is accepted. This means that the use of a drawing table in the production process has a significant effect on production results. Likewise for the use of the canting cap and padder. So the use of canting cap and padder has a significant effect on production results. As for the $\mathrm{t}$ value compared to the $\mathrm{t}$ table, it is found that the use of canting does not have a significant effect on production results. Likewise, the use of kenceng in the production process.

From this statistical test, the regression calculation equation is obtained, namely: $\mathrm{y}=-65,193+180,191 \mathrm{X} 1$ $+(-5,394 \mathrm{X} 2)+115,062 \mathrm{X} 3+85,395 \mathrm{X} 4+626,910 \mathrm{X} 5$

From the results of this description, it can be concluded that the variables of the drawing table, canting, canting cap, padder, and kenceng simultaneously have a positive and significant effect on production performance. Partially: the drawing table, canting cap, and padder have a significant effect on production performance. However, canting and kenceng variables do not have a significant effect on production performance. The calculation result of the coefficient of determination (R-Square) is 0.850 or $85.0 \%$.

\subsection{Create a Discussion}

The results showed that the production performance of batik SMEs in Central Java was influenced by the orientation of the technology used simultaneously. This means that the drawing table, canting, canting cap, padder, and kenceng have a shared influence to improve the batik production performance of batik SMEs in Central Java.

Canting cap, padder, and kenceng have a significant effect on the performance of written batik production. This means that the orientation of the canting cap technology used with copper affects the performance of batik production. Likewise, the technology orientation of padder and kenceng, respectively, has a significant effect on the performance of batik production. 
Meanwhile, the orientation of the drawing table technology and canting affects the production performance of written batik, but the effect is not significant. This can mean that the use of an ordinary or an ergonomic drawing table has very little effect on production performance. Likewise, the use of canting, both manual and electric, has very little effect on production performance. Therefore, in making written batik, the use of a drawing table, and canting with different technological orientations, the results have no significant or little effect on production performance.

In a study that applied a feeder tool to carry out the coloring process in batik SMEs, it was found that the labor requirement was reduced, the dyeing process time was faster, and there was an improvement in the posture of workers in doing their work [3].

In another study, a batik SMEs is quite good in terms of the performance of an internal business process perspective, where the average productivity is still quite high, the use of equipment technology is good, and the types of products developed are varied. The average employee has good enough skills and the workforce turnover is relatively small, the salary is adequate, the workplace is comfortable, and accommodates many workers around SMEs [4]. In a batik SME whose equipment technology is good, it has quite high productivity. This will be more complete if SMEs have sufficiently skilled employees.

A study of the performance of batik SMEs in Malang, East Java, especially those related to internal business processes, shows that the average level of productivity is $50 \%$, the number of patents generated reaches $60 \%$ of the target of SMEs, the percentage of employee skills improvement activities is around 52\%, the percentage of employees skilled work is an average of $87 \%$, the percentage of types of batik production techniques reaches $90 \%$, and the percentage of use of technological innovation is at the level of $70 \%$. It is almost on target but still needs improvement [5].

The applied technology orientation will be successful if it is equipped with the ability and skills to use these tools. A study was conducted on managers and batik craftsmen who carried out training and application of appropriate technology as a sample, so this research is census research. The results of the research show that the right training and technology to influence the empowerment of batik artisans through batik group activities and being trained through batik empowerment programs and the application of appropriate technology can increase production quantity and product quality [6].

However, in the business of making written batik cloth, entrepreneurs have different characteristics from entrepreneurs in other fields. Putri's research results [7] state that entrepreneurial characteristics have a significant effect on the performance of SMEs by $66 \%$.
Where the indicators of motivation are $11.6 \%$, optimism $17.7 \%$, self-efficacy $48.6 \%$, and self-management $35.4 \%$ have a significant effect on the formation of entrepreneurial characteristics in batik SMEs in Malang City.

\section{CONCLUSION}

The conclusion of this research showed that the production performance of batik SMEs in Central Java was influenced by the technology orientation of the tools used simultaneously. Drawing table, canting, canting cap, padder, and kenceng simultaneously have a significant effect on batik production performance in Batik SMEs in Central Java. The technology orientation of each tool, namely the drawing table, canting cap, and padder, affects the performance of written batik production. Meanwhile, the orientation of the canting and kenceng technology and does not affect the performance of written batik production. As the oldest batik-producing city in Indonesia, without abandoning the true principles of written batik, batik SMEs in Solo and Yogyakarta use slightly more modern and technology-oriented production tools to make written batik. Batik SMEs in other regions in Indonesia, can develop written batik production with canting cap, padder, and kenceng with a more modern orientation technology to improve the performance of their written batik.

\section{ACKNOWLEDGMENTS}

We would like to thank the Ministry of Research and Technology/National Agency for Research and Innovation of the Republic of Indonesia for grants given to researchers with the Higher Education Leading Applied Research (PTUPT) scheme and also to the Institute for Research and Community Service (LPPM), Widyagama University of Malang. Thank you also to all batik SMEs in Central Java, especially respondents in the Surakarta and Yogyakarta regions.

\section{REFERENCES}

[1] E. Kustiyah and Iskandar, "Batik Sebagai Identitas Kultural Bangsa Indonesia Di Era Globalisasi," Gema, vol. 30, no. 52, pp. 2456-2472, 2017.

[2] A. Muhi, "Teknologi Tepat Guna (TTG) dalam Perspektif Pemberdayaan Masyarakat. Makalah, disampaikan pada Acara Temu Karya Pendampingan Masyarakat Pedesaaan dalam Bidang Pemerintahan, Pembangunan dan Kemasyarakatan di Kabupaten Bekasi,” 2009.

[3] A. Irhandayaningsih, "Pengaruh Penggunaan Teknologi Tepat Guna dalam Meningkatkan Produktivitas UKM Batik Tulis di Kampung Batik Kauman Kota Pekalongan," Anuva, vol. 1, no. 1, p. 11, 2017, doi: 10.14710/anuva.1.1.11-18 
[4] C. F. Putri, I. Nugroho, and D. Purnomo, "Performance Measurement of SMEs of Malang Batik as a Result of Local Wisdom with Balanced Scorecard," IOP Conf. Ser. Mater. Sci. Eng., vol. 505, no. 1, 2019, DOI: 10.1088/1757899X/505/1/012022.

[5] D. P. CF Putri, I Nugroho, "Performance Measurement the AN Batik SMEs in Batu Using Smart System Method, International Conference on Science Technology and Engineering For Sustainable Development," ICoSTES, 2018.
[6] M. Andarwati, E. Subiyantoro, and T. Subadyo, "Pengaruh Pelatihan dan Penerapan Teknologi Tepat Guna (TTG) Terhadap Keberdayaan Pengrajin Batik Tulis Ramah Lingkungan," BRILIANT J. Ris. dan Konseptual, vol. 3, no. 3, pp. 280-286, 2018, [Online]. Available: http://eprints.unmer.ac.id/id/eprint/63.

[7] C. F. Putri, A. Hermawati, D. Purnomo, and K. Malang, "Pengaruh Karakteristik Individu Dan Kewirausahaan Terhadap Kinerja Ikm Batik Di Malang Raya," in Seminar Nasional Gelar Produk, 2017, pp. 3-8. 